\title{
PENERAPAN PENGGUNAAN IRAH-IRAH “DEMI KEADILAN BERDASARKAN KETUHANAN YANG MAHA ESA" DALAM KONTEKS PENCAPAIAN KEADILAN
}

\author{
Samuel Saut Martua Samosir, Fakultas Hukum Universitas Jember \\ Jl. Kalimantan No. 37, Kampus Tegalboto, Sumbersari, Jember, \\ E-mail : samuelsamosire@gmail.com
}

\begin{abstract}
Abstrak
Pasal 197 ayat (1) huruf a KUHAP, terdapat suatu kepala putusan atau irah-irah yang berbunyi "Demi Keadilan Berdasarkan Ketuhanan Yang Maha Esa" (selanjutnya disebut Keppu DKBKYME). Kepala putusan tersebut menegaskan terdapat kata keadilan yang berdasarkan Tuhan yang satu dan dimaha esakan, yang sebenarnya adalah hal utama yang dijadikan alasan bagi pemeriksaan di pengadilan, yaitu untuk mencari keadilan. Namun bagaimana jika ternyata isi dari putusan tersebut tidak memberikan keadilan bagi pihak yang diadili yang tercermin dengan adanya upaya hukum baik banding atau kasasi oleh pihak yang tidak menerima putusan. Terkait dengan isu hukum tersebut pada akhirnya ditarik sebuah paradigma baru bahwa konsep pemberian Keppu DKBDYME lebih tepat jika hanya bagi putusan yang telah mempunyai kekuatan hukum tetap (incracht), hal ini adalah upaya bahwa pencapaian keadilan materiil juga terwujud dan tergambarkan dalam keadilan yang bersifat formil prosedural.
\end{abstract}

Kata Kunci: Kepala Putusan, Keadilan, Hakim

\section{Abstract}

It is required that every head of the verdict has specific nomenclature "On behalf of Justice in the name of one and only God" which entrenched in Article 197 paragraph 1of the Criminal Code Procedure. The head of the verdict stressed that there is a word of justice based on the one and only God which has the main purpose is for the court examination in order to pursue justice, but there is a problem when the contents of the ruling did not provide justice for the prosecuted party, it can be indicated that the case filed to the appeal court by parties whose refuse the decision. According to the legal issues there exist the new paradigm to the concept of the head of the verdict which states "On behalf of Justice in the name of one and only God" only for decisions that have permanent legal force, this is an effort to achieve procedural justice and moral Justice

Keywords: Head of Verdict, Justice, Judge

\section{LATAR BELAKANG}

Keadilan berkaitan pula dengan kekuasaan kehakiman karena suatu bangsa yang mengakui hukum sebagai suatu dasar, maka kekuasaan kehakiman mengejewantahkan suatu lembaga yang memberikan patokan dalam menguatkan isi dan aturan hukum positif serta pengaktualisasian bagi hakim ketika dia membuat putusan dalam sidang pengadilan, oleh karena itu seluruh norma hukum yang dibuat dan diundangkan oleh suatu negara yang memberikan usaha perlindungan keamanan dan keselamatan masyarakat guna memberikan kesejahteraan kepada rakyat, maka hal ini sangat berkaitan erat dengan kekuasaan kehakiman dimana hakim mempunyai kekuasaan dan wewenang dalam memberikan isi kekuatan kepada norma hukum dalam suatu perundang-undangan dan norma hukum yang terdapat dalam peraturan hukum. ${ }^{1}$

\footnotetext{
${ }^{1}$ Nanda Agung Dewantara, Masalah Kebebasan Hakim dalam Menangani Suatu Perkara

Pidana, Jakarta: Aksara Persada Indonesia, 1987, h. 36.
} 
Proses penanganan suatu perkara pidana tentunya haruslah berakhir dengan adanya putusan akhir atau yang dapat disebut dengan vonis hakim. Di dalam hukum pidana formil, suatu putusan pengadilan adalah suatu keyakinaan hakim yang dinyatakan dalam suatu sidang yang diketahui oleh umum yang dapat menyatakan penghukuman kepada seseorang (pemidanaan), akan tetapi hakim dapat juga memberikan putusan yang bebas atau lepas dari hukum asalkan sesuai dengan ketentuan hukum pidana yang berlaku saat ini dan tegas terdapat pengaturan perundangan yang mengaturnya ${ }^{2}$. pendapat lain juga mengatakan bahwa putusan pengadilan tersebut adalah suatu proses yang harus dilalui dalam penanganan suatu perkara yang dipimpin oleh para hakim yang memeriksa perkara tersebut karena jabatannya sehingga mampu memberikan putusan yang berupa pemidanaan atau lepas dari tuntutan atau bebas dari hukum, yang dalam pembuatannya dibuat secara tertulis dan merupakan tahap akhir dalam suatu penyelesaian perkara. ${ }^{3}$

Mengacu pada ketentuan dalam hukum acara formil, ${ }^{4}$ terdapat suatu kepala putusan atau irah-irah yang sangat penting yang berbunyi "Demi Keadilan Berdasarkan Ketuhanan Yang Maha Esa" (Keppu DKBKYME), dengan tidak adanya penulisan Keppu DKBKYME dalam sebuah putusan pidana, maka dengan tegas dalam KUHAP dinyatakan bahwa putusan itu akan batal demi hukum. Keppu DKBDYME tersebut sangat berkaitan erat dan berlandaskan pada asas penyelenggaraan kekuasaan kehakiman yang menyatakan bahwa peradilan dilakukan untuk keadilan yang didasarkan pada Tuhan Yang Maha Esa",5 dan hal ini berkaitan pula salah satu upaya penjaminan negara kepada setiap warga negara dalam kemerdekaan dan kebebasan memilih agamanya dan beribadah menurut agama dan kepercayaannya sesuai dengan keyakinan tanpa ada paksaan dari orang lain. ${ }^{6}$

Irah-irah yang termuat dalam suatu putusan tersebut sangat jelas sekali terdapat kata "Keadilan" yang didasari oleh Ketuhanan Yang Maha Esa. Memaknai keadilan merupakan nilai dalam kehidupan manusia guna meraih kemanfaatan kehidupan. Keadilan menunjukkan keadilan sebagai atribut hukum dan sebagai suatu tindakan menentukan hak atau hukuman. Istilah keadilan (iustitia) didapat dari kata "adil" yang diartikan sebagai upaya penyelesaian suatu hal yang tidak timpang sebelah, bersifat netral namun tetap membela dan pada memihak kepada yang benar, seyogyanya dan tidak melakukan kesewenangan kepada orang lain. Keadilan sangat berhubungan erat dengan interaksi baik berupa sikap dan tingkah laku antar manusia. Keadilan adalah suatu hal yang menuntut kepada semua orang agar dapat memberikan sesama manusia perlakukan sesuai dengan hak dan kewajibannya, yang tidak diskriminatif namun memberikan sesuatu dengan apa yang seharusnya diterima. ${ }^{7}$ Keadilan dapat diartikan

\footnotetext{
2 Pasal 1 angka 11 KUHAP.

${ }^{3}$ Lilik Mulyadi, Putusan Hakim dalam Hukum Acara Pidana, Bandung: Citra Adita Bakti, 2007, h.21.

${ }^{4}$ Pasal 197 ayat (1) huruf a Kitab Undang-Undang Hukum Acara Pidana (KUHAP).

${ }^{5}$ Pasal 2 ayat (1) UU Nomor 48 Tahun 2009 tentang Kekuasaan Kehakiman.

6 Penjelasan pasal 2 ayat (1) UU Nomor 48 Tahun 2009 tentang Kekuasaan Kehakiman.

${ }^{7}$ John Rawls, Teori Keadilan (A Theory of Justice), Diterjemahkan oleh Uzair Fauzan dan Heru Prasetyo, Yogyakarta: Pustaka Pelajar, 2006, h. 212.
} 
sebagai suatu kebajikan yang berlaku universal dimana fungsi dan tujuannya adalah memperoleh 'bonum commune' atau kebaikan bagi semua manusia. ${ }^{8}$ Keadilan bagi Aristoteles diartikan sebagai suatu kelayakan dalam perbuatan orang sebagai posisi tengah yang terdapat dalam dua buah pucuk luar yang begitu banyak dan begitu sedikit. Keadilan adalah suatu perbuatan yang ditujukan untuk memberikan sesuatu kepada setiap manusai dengan dengan apa yang seharusnya ia peroleh sesuai dengan haknya dengan tidak memberikan terlalu banyak dan juga tidak terlalu sedikit, ${ }^{9}$ sehingga dalam konsep keadilan tersebut dapat dimaknai bahwa terhadap suatu putusan perkara pidana, maka putusan tersebut telah menggambarkan bahwa terdapat rasa keadilan di dalamnya yang berdasar kepada makna Tuhan Yang Esa dan dan pemberian perlakuan kepada semua orang sesuai dengan hak dan kewajibannya.

Namun makna tersebut menjadi suatu yang perlu dipertanyakan kembali mengenai makna hakiki dari kata "Keadilan" dalam irah-irah suatu putusan tersebut yang bahkan dipertegas bahwa keadilan tersebut berdasarkan "Ketuhanan Yang Maha Esa", mengingat bahwa didalam KUHAP sendiri masih memberikan keleluasaan bagi pihak yang berperkara untuk dapat melakukan upaya hukum dimana terdapat hak bagi terdakwa atau penuntut umum untuk tidak puas dan mempertanyakan kembali putusan hakim yang ia telah peroleh yaitu dengan cara upaya hukum biasa dan upaya hukum luar biasa yang telah diatur sebagaimana hukum acara pidana di Indonesia. ${ }^{10}$

Hakim yang memeriksa suatu perkara haruslah mampu melakukan penelitian hukum terhadap perkara yang ditanganinya, sejalan dengan apa yang diutarakan oleh Peter Mahmud, tentunya dalam penelitian hukum adalah upaya mencari kebenaran koherensi yang berawal dari apa yang dipercaya dalam suatu pikiran guna memperoleh apakah suatu putusan tersebut benar, maka putusan tersebut haruslah sesuai dengan suatu pertalian sistem pernyataan pernyataan atau lebih tepat dengan proposisi lainnya yang ditemukan dalam analisa sehingga dapatlah ditemukan sinkronisasi kehendak yang dianalisis dengan aturan aturan yang berisi nilai nilai yang dijadikan panduan dalam melakukan penelitian, sehingga jika dalam analisa penelitian hukum tersebut ditemukan kesesuaian antara kehendak dan nilai yang diinginkan dalam aturan atau undangundang, maka hal inilah yang dapat diartikan sebagai suatu kebenaran, namun jika tidak ditemukan kesesuaian, maka hal ini yang disebut dengan tidak ada kebenaran (falsity). ${ }^{11}$

Sebuah putusan yang masih dilakukan upaya hukum menandakan adanya ketidakpuasan terhadap hakim dalam upaya mencari kebenaran tersebut, sehingga

\footnotetext{
${ }^{8}$ Jude P. Dougherty, Western Creed, Western Identity : Essays in Legal and Social Philosohy, CUA Press, 2010, h.176

${ }^{9}$ RH. Wiwoho, Keadilan Berkontrak, Jakarta: Penaku, 2017, h.138.

${ }^{10}$ Pemahaman tentang upaya hukum biasa yang dalam KUHAP diatur dalam Pasal $233-258$ KUHAP, dapat berupa antara lain dengan upaya hukum Banding, Kasasi sebagai dengan persyaratan dalam hukum acara pidana, sedangkan Upaya Hukum Luar Biasa dalam hukum acara pidana diatur dalam Pasal 259-269 KUHAP berupa Pemeriksan Tingkat Kasasi Demi Kepentingan Hukum (Pasal 259 KUHAP), Peninjauan Kembali Putusan Pengadilan yang telah Mempunyai Kekuatan Hukum Tetap (Pasal 263 KUHAP).

11 Ibid, h.22.
} 
berdasarkan hal tersebut, dapat ditarik sebuah isu hukum, yaitu masih tepatkah Keppu DKBKYME tetap disematkan dalam suatu putusan, sedangkan putusan tersebut masih dilakukan upaya hukum (belum berkekuatan hukum tepat)? Isu hukum ini muncul tidak terlepas dari sebuah pemikiran apakah irah-irah tersebut hanyalah simbol belaka dalam pemenuhan formalitas putusan atau bahkan tidak bermakna sama sekali, jika ternyata dalam putusan tersebut mengalami perubahan setelah dilakukan upaya hukum banding atau kasasi atau ternyata putusan tersebut dinyataan tidak tepat oleh hakim pengadilan di atasnya dan kemudian pengadilan diatasnya membatalkan putusan tersebut, dimanakah letak kebenaran koherensi dari Keppu DKBKYME tersebut jika ternyata putusan tersebut dibatalkan padahal sebagaimana diketahui, kepala putusan tersebut menegaskan bahwa putusan tersebut terdapat suatu kata keadilan yang berdasarkan akan Kemahaesaaan dari Tuhan yang sebenarnya adalah hal utama yang dijadikan alasan bagi pemeriksaan di pengadilan, yaitu untuk mencari keadilan, namun ternyata isi dari putusan tersebut tidak memberikan keadilan bagi pihak yang diadili.

Berdasarkan latar belakang diatas, maka perlulah dikaji dan ditelusuri dengan menggunakan analisa hukum, terkait prinsip irah-irah "Demi Keadilan Berdasarkan Ketuhanan Yang Maha Esa".

\section{RUMUSAN MASALAH}

1. Apakah makna irah-irah "Demi Keadilan Berdasarkan Ketuhanan Yang Maha Esa" dalam sebuah putusan perkara pidana?

2. Putusan pidana apakah yang tepat untuk tetap menggunakan "Demi Keadilan Berdasarkan Ketuhanan Yang Maha Esa" dalam kepala putusannya?

\section{METODE PENELITIAN.}

\section{a. Tipe Penelitian.}

Penelitian ini menggunakan metode yang bersifat normatif dimana dalam melakukan penelitian adalah meneliti perundang-undangan, yurisprudensi, serta nilainilai hukum yang hidup dalam masyarakat. Penelitian ini menitik beratkan tentang upaya analisa dengan menggunakan perundang-undangan serta konsep hukum yang berkaitan dengan hakikat dari Keppu DKBKYME dalam sebuah putusan perkara pidana.

\section{b. Pendekatan Masalah}

Dalam suatu penelitian Hukum tentunya terdapat pendekatan masalah guna memperoleh bahan kajian dari berbagai sudut pandang untuk menjawab isu hukum yang akan dipecahkan ${ }^{12}$. Dalam penelitian mengenai Keppu DKBKYME ini, maka pendekatan yang digunakan dalam penelitian hukum ini adalah meliputi pendekatan perundang-undangan (statute approach), serta konseptual (conceptual approach).

12 Ibid, h. 133. 


\section{c. Sumber Bahan Hukum}

Untuk menjawab permasalahan yang diketengahkan dalam penelitian digunakan sumber bahan hukum, yang meliputi bahan hukum primer dan bahan hukum sekunder. Bahan hukum primer meliputi peraturan perundang-undangan dalam penelitian ini adalah semua peraturan perundang-undangan yang terkait dengan Keppu DKBKYME" dalam sebuah putusan perkara pidana.

Bahan hukum sekunder meliputi buku-buku teks hukum, skripsi, tesis, disertasi, jurnal-jurnal hukum, dan komentar-komentar atas putusan pengadilan yang berkaitan dengan Keppu DKBKYME dalam sebuah putusan perkara pidana.

\section{d. Pengolahan dan Analisis Bahan Hukum}

Bahan-bahan hukum yang diperoleh, baik berupa bahan hukum primer maupun bahan hukum sekunder diuraikan dan disajikan dalam penulisan untuk menjawab rumusan masalah dalam penelitian. Setelah bahan bahan hukum terkumpul langkah selanjutnya adalah melakukan inventarisasi terhadap bahan hukum, kemudian terhadap inventarisasi bahan hukum tersebut ditarik sebuah analisa dan upaya penjabaran untuk menemukan kebenaran koherensi sehingga pada akhirnya akan diperoleh suatu kesimpulan yang merupakan jawaban terhadap isu hukum yang dihadapi dengan sekaligus memberikan apa yang seharusnya dilakukan untu mengatasi permasalahan hukum yang dihadapi tersebut.

\section{PEMBAHASAN}

\section{Makna Irah-Irah "Demi Keadilan Berdasarkan Ketuhanan Yang Maha Esa" dalam Suatu Putusan Perkara Pidana}

Kepala putusan dalam perkara pidana yang menyebutkan "Demi Keadilan Berdasarkan Ketuhanan Yang Maha Esa", sebenarnya sangat berhubungan dengan asas penyelenggaraan kekuasaan kehakiman yaitu apa yang termuat dalam ketentuan pasal 2 ayat (1) yang menyatakan Peradilan dilakukan "Demi Keadilan Berdasarkan Ketuhanan Yang Maha Esa", maka dalam pembahasan ini penulis akan menguraikan makna dalam ketentuan pasal 2 ayat (1) UU Kekuasaan Kehakimam tersebut untuk menemukan prinsip yang terkandung dalam irah-irah suatu putusan perkara pidana.

Memaknai peradilan pidana secara umum tidak terlepas dari adanya suatu sistem yang disebut dengan sistem peradilan pidana, Barda Nawawi Arief, memberikan pemahaman bahwa Sistem Peradilan Pidana adalah sebagai upaya atau pola dalam penegakan hukum pidana dimana dalam prosesnya sangat berkaitan erat dengan perundang-undangan itu sendiri, atau dengan jika melihat secara lebih detail dan dalam, maka perundang-undangan pidana adalah suatu penegakan hukum pidana in abstracto yang pada akhirnya akan dimunculkan pada suatu penegakan hukum in concrecto. ${ }^{13}$ Sejalan dengan hal tersebut, dengan mengambil pendapat dari Frans Hendra Winarta, dapat ditemukan bahwa tujuan sistem peradilan pidana (criminal justice system) adalah upaya mencapai tujuan dalam upaya pencegahan kejahatan, mengurangi pengulangan kembali suatu kejahatan dan melakukan upaya rehabilitasi agar dapat

${ }^{13}$ Barda Nawawi Arief, Teori-Teori dan Kebijakan Pidana, Bandung: Alumni, 1992, h. 197. 
dikembalikan kembali kepada masyarakat dan untuk memperoleh tujuan tersebut haruslah terdapat adanya suatu sistem kerjasama yang terpadu antara kepolisian, kejaksaan, pengadilan, lembaga pemasyarakatan serta advokat. ${ }^{14}$

Awal putusan dalam suatu perkara yang dimulai dengan ungkapan yang religi yaitu "Demi Keadilan Berdasarkan Ketuhanan Yang Maha Esa" adalah suatu gambaran tujuan lembaga peradilan di Indonesia yang dimanatkan untuk dapat melakukan penegakan hukum guna memperoleh keadilan yang didasarkan pada Tuhan Yang Maha Esa untuk dapat memberikan dan memunculkan ketentraman, ketertiban, dan kedamaian dalam masyarakat. 15

Peradilan dalam Kamus Besar Bahasa Indonesia diartikan sebagai segala sesuatu mengenai perkara pengadilan: lembaga hukum bertugas memperbaiki, 16 namun pemaknaan peradilan lebih khusus dapat ditemukan dengan membandingkan ketentuan yang terdapat dalam UU kekuasaan Kehakiman yang memberikan pengaturan bahwa dalam suatu peradilan negara maka dalam penerapannya dan penegakan hukum dan keadilan harus berdasarkan pada apa yang terkandung dalam nilai-nilai yang terdapat dalam Pancasila17 dan sebuah pengadilan haruslah mampu untuk mengadili sesuai dengan hukum yang berlaku dengan tidak melakukan diskriminasi terhadap orang, yang dalam upaya pengadilan tersebut adalah untuk memberikan bantuan kepada para pencari keadilan dengan memberikan upaya mengatasi berbagai hambatan serta halangan sehingga diperoleh suatu peradilan yang bersifat sederhana, tidak bertele-tele (cepat) dan tidak membutuhkan biaya besar. ${ }^{18}$ Berkaitan dengan hal tersebut maka dapat disimpulkan bahwa proses untuk menemukan dan menegakkan keadilan adalah apa yang disebut dengan peradilan, sedangkan wadah atau tempat untuk membuat terwujudnya proses tersebut adalah apa yang disebut dengan pengadilan.

Menurut Kamus Bahasa Indonesia pengertian “Demi' dapat mengandung berbagai artian dari kalimat yang akan menggunakan kata tersebut, demi dapat diartikan untuk (kepentingan), tatkala; pd ketika; segera setelah, atas nama (Tuhan, untuk bersumpah), lepas, sebagai; seperti (untuk membandingkan). ${ }^{19}$ "Demi" mempunyai makna "untuk" atau "atas nama" keadilan yang bersumber dari kekuasaan yang maha tinggi yaitu Tuhan, yang bagi masyarakat muslim disebut Allah Yang Maha Kuasa, yang bukan hanya wajib disembah, melainkan juga wajib dipatuhi dan ditaati segenap perintah-Nya dan dijauhi segala larangan-Nya bagu umat muslim..$^{20}$ Terhadap Keppu DKBKYME ini ada pula yang mengartikan dengan sudut pandang lain bahwa Keppu DKBKYME

\footnotetext{
${ }^{14}$ Frans Hendra Winarta, Bantuan Hukum Suatu Hak Asasi Manusia Bukan Belas Kasihan, Jakarta: PT. Elexmedia Komputindo, Kelompok Gramedia, 2000, h. xi.

${ }^{15}$ Antonius Sudirman, Hati Nurani Hakim dan Putusannya: Suatu Pendekatan Dari Perspektif Ilmu Hukum Perilaku (Behavioral Jurisprudensi) Kasus Hakim Bismar Siregar, Bandung: Citra Aditya Bakti, 2007, h. 1.

${ }^{16}$ http://kbbi.co.id/arti-kata/demi, diunduh tanggal 12 Desember 2018, pkl 11.07 pm.

${ }_{17}$ Pasal 2 ayat (2) UU Kekuasaan Kehakiman.

18 Pasal 4 UU Kekuasaan Kehakiman.

${ }^{19} \mathrm{http}: / /$ kbbi.co.id/arti-kata/demi, diunduh tanggal 12 Desember 2018, pkl 11.07 pm.

${ }^{20}$ HMA. Kuffal, Demi Keadilan Berdasarkan Ketuhanan Yang Maha Esa, Hakim : Antara Gaji, Keadilan, Kejujuran dan Ketaqwaan, Malang: UMM Press, 2012, hlm 22-24.
} 
ditujukan agar setiap putusan pengadilan melahirkan suatu putusan yang mempunyai kekuatan eksekutorial yang artinya bahwa putusan tersebut bisa dilakukan secara paksa jika ada pihak yang dikalahkan namun tidak mau secara sukarela melaksanakan isi putusan tersebut. ${ }^{21}$

Terhadap pemahaman tentang Keppu DKBKYME ini jika disandingkan dengan pemahaman sebagaimana disebutkan dalam UU Kekuasaan Kehakiman memberikan arti bahwa Peradilan dilakukan "Demi Keadilan Berdasarkan Ketuhanan Yang Maha Esa" adalah sejalan dengan apa yang terdapat dalam pasal 29 UUD 1945 yang menegaskan bahwa Negara Indonesia adalah negara yang berdasarkan akan Ketuhanan Yang Maha Esa serta memeberikan jaminan bagi semua Warga Negara Indonesia untuk dapat memilih agamanya masing masing sesuai dengan keyakinannya serta dapat melakukan ibadat menurut tata aturan dalam agama dan kepercayaannya tersebut, ${ }^{22}$ maka dapat diartikan bahwa peradilan di Indonesia dilakukan untuk kepentingan keadilan yang didasarkan akan nilai Ketuhanan Yang Maha Esa, peradilan yang ditujukan untuk mewujudkan nilai adil yang mengarah kepada keadilan yang sejalan dengan nilai nilai agama dan kepercayaan yang mempercayai adanya Tuhan sebagai pencipta manusia.

Hakim yang memeriksa dan memutus suatu perkara, maka dalam sebuah putusannya haruslah memberikan putusan yang bernilai adil yang berupa keadilan yang diperoleh dengan menyeimbangkan antara hak dan kewajiban serta putusan tersebut haruslah mempunyai nilai martabat yang diartikan sebagai putusan yang menciptakan kemanusiaan dengan melahirkan suatu putusan yang memberikan perlakukan dan memegang teguh suatu nilai nilai kemanusiaan sesuai dengan hakikat dan apa yang diinginkan bagi para pencari keadialan atau pihak pihak yang berperkara. ${ }^{23}$ Andi Hamzah menyimpulkan bahwa hakim yang mempunyai kewenangan berdasarkan jabatannya haruslah mampu membuat putusan yang akan diutarakan dalam persidangan yang dilakukan secara terbuka bagi masyarakat dengan tidak melepaskan diri dari suatu proses dan prosedur hukum acara pidana yang nantinya akan berisikan dalam amar putusannya apakah seseorang akan dipidana, atau akan dilepaskan dari segala tuntutan hukum atau bahkan dapat dibebaskan yang dibuat secara tertulis untuk mengakhiri suatu perkara yang ditanganinya. ${ }^{24}$ Selain itu sebuah putusan yang dibuat oleh hakim selain juga mengacu kepada hukum dan perundangan yang berlaku, tentunya dalam putusan tersebut haruslah mencerminkan penggunaan hati nurani agar dalam putusan yang dibuatnya dapat memberikan keadilan namun juga memberikn kemanfaatan setelah putusan tersebut dibuat dan diberlakukan, meskipun sebuah putusan adalah untuk menyelesaikan perkara dalam upaya penegakan hukum dan keadilan, namun hal

${ }^{21}$ Dahlan Sinaga, Kemandirian dan Kebebasan Hakim Memutus Perkara Pidana Dalam Negara Hukum Pancasila, Suatu Perspektif Teori Keadilan Bermartabat, Bandung: Nusa Media, 2015, h. 127.

22 Penjelasan pasal 2 ayat (1) UU Nomor 48 tahun 2009 tentang Kekuasaan Kehakiman.

${ }^{23}$ Teguh Prasetyo, Hukum dan Sistem Hukum Berdasarkan Pancasila, Yogyakarta: Media Perkasa, 2013, h.92-93.

${ }^{24}$ Andi Hamzah, Hukum Acara Pidana Indonesia, Jakarta: PT. Rineka Cipta, 2000, h.63. 
ini akan dapat menyebabkan tidak muncuknya nilai keadilan dan nilai kemanfaatan, jika dalam putusan tersebut tidak menggunakan hati nurani. ${ }^{25}$

Makna "Demi Keadilan Berdasarkan Ketuhanan Yang Maha Esa”, diartikan bahwa upaya menegakkan hukum yang diinginkan adalah memberikan keadilan yang didasari akan adanya Tuhan, dimana penegakan hukum tersebut dilakukan dengan mendasarkan pada rida Tuhan, sehingga dalam upaya menegakkan hukum tersebut dapat tergambarkan adanya upaya menegakkan hukum yang mengacu pada kebenaran yang berasal dari kehendak dan restu dari Tuhan Yang Maha Esa, sehingga penegakan hukum bukan semata atas keinginan dari penguasa akan tetapi benar-benar sebagai perwujudan mencapai keadilan yang diinginkan oleh Tuhan Yang Maha Kuasa. ${ }^{26}$ Pendapat ini juga sejalan dengan Barda Nawawi Arief yang bahkan memberikan penegasan bahwa seorang Hakim yang akan memberikan suatu putusan haruslah berpijak pada keadilan yang didasarkan pada Ketuhanan yang esa, oleh karenanya sebelum hakim akan memberikan suatu putusan, terlebih dahulu ia harus bermunajat kepada Tuhan sehingga atas nama Tuhan pada akhirnya putusan itu diucapkan disertai dengan sumpahnya kepada Tuhan Yang Maha Esa. ${ }^{27}$

Putusan hakim harus dapat diterima oleh masyarakat, yang dalam artian bahwa hakim dalam memutuskan perkara tidak hanya berpatokan kepada hukum tertulis saja sehingga tidak dikatakan sebagai corong undang undang, namun juga harus mempu melihat nilai nilai yang terkandung dalam masyarakat meskipun bukan juga diartikan sebagai corong masyarakat ${ }^{28}$. Pada hakekatnya putusan pengadilan haruslah merupakan putusan yang mengandung keadilan substansial, dimana keadilan ini haruslah mampu secara tepat bagaimana membedakan antara keadilan individual dengan keadilan sosial,yang dengan kata lain bahwa nilai ideal suatu putusan akan tergambarkan dengan baik jika keadilan individual tercermin dalam keadilan sosial, pemaknaan hal ini dapat juga digambarkan bahwa suatu keadilan individual menggantungkan diri pada keadilan sosial karena sebenarnya suatu nilai keadilan sosial merupakan perubahan yang lebih diutamakan daripada nilai keadilan individu. ${ }^{29}$

Keadilan, kepastian hukum dan kegunaan hukum untuk mencapai tujuan yang lebih baik adalah suatu tujuan hukum yang dicitakan oleh semua aparat penegak hukum,oleh

${ }^{25}$ HM. Soerya Respationo, "Putusan Hakim: Menuju Rasionalitas Hukum Refleksif dalam Penegakan Hukum", Jurnal Hukum Yustisia, No.86 Th. XXII Mei-Agustus, 2013, Surakarta: Fakultas Hukum Universitas Sebelas Maret Surakarta, h.43.

${ }^{26}$ M.Yahya Harahap, Pembahasan Permasalahan dan Penerapan KUHAP,Pemeriksaan Sidang Pengadilan, Banding, Kasasi, dan Peninjauan Kembali, Jakarta: Sinar Grafika, 2005, h.360

${ }^{27}$ Barda Nawawi Arief, Sistem Peradilan Pidana Terpadu (Intergrated Criminal Justice System, Semarang: Universitas Diponegoro, 2006, h.20.

${ }^{28}$ Tata Wijayanta dan Herry Firmansyah, "Perbedaan Pendapat Dalam Putusan Putusan Di Pengadilan Negeri Yogyakarta dan Pengadilan Negeri Sleman", Jurnal Berkala Mimbar Hukum,Vol. 23 No. 1 Februari 2011, Yogyakarta: Fakultas Hukum Universitas Gadjah Mada, h. 46.

${ }^{29}$ Bagir Manan, Sistem Peradilan Berwibawa (Suatu Pencarian), Jakarta: Mahkamah Agung RI, 2007, h. 13. 
karenanya hal ini merupakan kewajiban yang melekat pada semua penegak hukum, 30 namun hakim memiliki posisi yang lebih istimewa, kewenangannya untuk memeriksa dan dan mengadili serta memberikan putusan yang nantinya akan didasarkan pada Ketuhanan Yang Maha Esa adalah wujud kewenangan yang bersifat merdeka dan mandiri selaku lembaga peradilan yang memegang kekuasaan kehakiman. Sebagai wakil Tuhan yang dalam setiap putusannya selalu dengan berani mengatasnamakan Tuhan dalam memberikan putusan, maka hakim diartikan sebagai konkretisasi hukum dan keadilan yang bersifat abstrak, 31 putusan hakim haruslah putusan yang dapat dilaksanakan oleh pihak yang menginginkan keadilan, sehingga hakim tidak boleh sedikitpun ragu-ragu akan putusannya, akan tetapi tetap berpegang teguh pada jalan kebenaran serta tidak berat sebelah atau memihak, oleh karenanya putusan hakim harus mampu memberikan dan menerapkan serta menghubungan dengan dasar hukum yang jelas dari setiap perkara yang ditanganinya dengan Surat Dakwaan yang menjadi dasar pemeriksaan dengan fakta yang ditemukan dalam persidangan, karena hal ini juga untuk menentukan seberapa berat atau ringannya seseorang dapat dikenai pidana. ${ }^{32}$

Terhadap pemaknan pada ketentuan pasal 2 ayat (1) UU Kekuasaan Kehakiman jika merujuk kembali pada undang-undang sebelumnya ${ }^{33}$ lebih menegaskan bahwa ketentuan tersebut adalah menjadi syarat bathin dari para hakim untuk memberikan keadilan yang diperoleh dari undang undang dan oleh karenanya hal ini menjadi bentuk pertanggung jawaban yang berat yang dibebankan kepadanya dimana dalam sumpah jabatannya diisyaratkan bahwa selain dia bertanggung jawab kepada hukum, ataukepada dirinya sendiri dan juga kepada rakyat namun hal yang terutama bahwa ia juga bertanggung-jawab kepada Tuhan Yang Maha Esa, yang dalam pemaknaannya dirumuskan dengan ketentuan, bahwa peradilan dilakukan "Demi Keadilan Berdasarkan Ketuhanan Yang Maha Esa". ${ }^{34}$

Bismar Siregar mengatakan bahwa Keppu DKBKYME dalam sebuah putusan adalah penegasan sebuah sumpah atas nama Tuhan, yang oleh karenanya ia wajib mencari dan menggali, kemudian merumuskan nilai-nilai hukum dan keadilan, yang menjadi dasar keputusan yang bersesuaian dengan "perasaan" dan "rasa keadilan" yang hidup dalam masyarakat. ${ }^{35}$ Hakim diperingatkan jangan kaku, jangan terpaku pada harfiah peraturan, hakim wajib memutus perkara, memberi keadilan sebagai orang yang bijaksana, yaitu menunjukkan "keluwesan" sikap hakim, meneliti, menelaah setiap perkara. ${ }^{36}$ Namun

\footnotetext{
${ }^{30}$ Aloysius Wisnubroto, Hakim dan Peradilan di Indonesia dalam Beberapa Aspek Kajian, Yogyakarta: Universitas Atmajaya, 1997, h.65

${ }^{31}$ Zulkarnain, Praktik Peradilan Pidana, Panduan Praktis Memahami Peradilan Pidana, Malang: Setara Press, 2016, h.5.

32 Wirjono Prodjodikoro, Azas Azas Hukum Pidana di Indonesia, Bandung: Refika Adhitama, 2003, h. 23.

${ }^{33}$ Undang-Undang Nomor 14 Tahun 1970 tentang Ketentuan-Ketentuan Pokok Kekuasaan Kehakiman.

${ }^{34}$ Penjelasan umum Undang-Undang Nomor 14 Tahun 1970 tentang Ketentuan-Ketentuan Pokok Kekuasaan Kehakiman.

${ }^{35}$ Bismar Siregar, Rasa Keadilan, Surabaya: PT. Bina Ilmu, 1996, h. 5.

${ }^{36}$ Ibid, h. 101.
} 
jika pemaknaan bahwa Keppu DKBKYME dalam sebuah putusan hanyalah diartikan sebagai penegasan sebuah sumpah dari seorang hakim saja tentunya hal ini telah dilakukan dengan sumpah jabatan hakim. ${ }^{37}$ Dengan adanya sumpah jabatan ini, tentunya meskipun tidak disebutkan Keppu DKBKYME dalam sebuah putusan yang dibuat oleh hakim, hakim tersebut tetap bertanggung jawab penuh pada putusan yang dibuatnya kepada Tuhan karena pada saat ia menduduki jabatan sebagai hakim, sumpah jabatan telah mengikatkan akan tanggung jawabnya kepada Tuhan untuk dapat memberikan putusan yang seadil-adilnya.

Pemaknaan sebagaimana disebutkan di atas seharusnya menjadi titik tumpu jika dalam ketentuan pasal 197 ayat (1) KUHAP yang menegaskan adanya kewajiban Kepala Putusan yang menegaskan adanya pemaknaan "Demi Keadilan Berdasarkan Ketuhanan Yang Maha Esa", maka sudah seharusnya isi putusan tersebut berisi tentang suatu proses dalam mencapai suatu keadilan yang dapat dipertanggungjawabkan kebenarannya dihadapan Tuhan Yang Maha Esa, namun juga ditujukan kepada tanggung jawab kepada diri sendiri dan tanggung jawab moral kepada rakyat. bentuk pertanggung jawaban kepada Tuhan tentunya diartikan bahwa dalam membuat suatu putusan, maka seorang hakim harus memutuskan sejalan dengan norma/kaidah agama dan kepercayaannya, dan dalam kepada diri sendiri, diartikan sebagai tanggung jawabnya sebagai penegak hukum yang bertugas untuk mengadili suatu perkara, dan kepada rakyat dimana dalam putusan tersebut harus mencerminkan rasa adil, yang mampu untuk diamini kebenarannyaa oleh seluruh rakyat pada umumnya.

\section{Penggunaan Irah-Irah "Demi Keadilan Berdasarkan Ketuhanan Yang Maha Esa" Hanya Bagi Putusan yang Telah Berkekuatan Hukum Tetap}

Memaknai keadilan tidak terlepas dari perlindungan dan kemanfaatan, karena nilai suatu keadilan adalah memuat hal hal yang utama yang secara umum mengarahkan kepada setiap orang untuk dapat mewujudkan perlindungan atas hak yang telah dijamin oleh hukum (unsur hak) sehingga dapat memberikan manfaat kepada setiap manusia (unsur manfaat), ${ }^{38}$ sehingga sejalan dengan pemaknaan tersebut, maka perwujudan keadilan dapat tercermin jika dalam putusan perkara pidana, antara Jaksa Penuntut Umum selaku wakil negara dan pelaku kejahatan (terdakwa) dapat menerima putusan yang dibuat oleh hakim yang memeriksa suatu perkara pidana tanpa melakukan upaya hukum lagi (inkracht).

Kepala Putusan adalah sebagai bentuk dari keadilan formal (formal justice) yang pada hakekatnya dbentuk dengan pemaknaan bahwa jika terdapat suatu perakara yang sama, maka dalam perlakukan terhadap perkara itu haruslah sama dengan perlakuan perkara sebelumnya, begitu juga sebaliknya, jika memang ditemukan ada hal yang berbeda terhadap suatu perkara dengan perkara lain, maka tentunya hal ini juga mendapatkan

\footnotetext{
${ }^{37}$ Pasal 17 Undang-Undang Republik Indonesia Nomor 8 Tahun 2004 tentang Perubahan Atas Undang-Undang Nomor 2 Tahun 1986 tentang Peradilan Umum.

${ }^{38}$ E. Fernando M. Manullang, Menggapai Hukum Berkeadilan Tinjauan Hukum Kodrat dan Antinomi Nilai, Cetakan 1, Buku Kompas, Jakarta: PT. Kompas Media Nusantara, 2007, h. 100.
} 
perlakukan yang berbeda. Keadilan formal diibaratkan sebagai suatu tempat/wadah yang belum terisi, sehingga tempat/wadah tersebut harus bisa dimasukkan akan sebuah putusan yang berisi keadilan yang substansial yaitu suatu keadilan yang memberikan suatu penyelesesaian hukum dan memaknai hukum yang akan diterapkan tersebut adalah benar benar sudah adil. ${ }^{39}$

Dengan putusan yang diterima oleh pihak yang berperkara dapat diartikan bahwa pihak yang berperkara memaknai bahwa putusan tersebut telah memberikan keadilan sesuai dengan apa yang terbukti dalam persidangan, dapat diartikan pula bahwa keyakinan hakim yang diperoleh dari pembuktian dipersidangan telah diakui kebenarannya dan diterima oleh pihak yang berperkara, sehingga makna kepala putusan yang menginginkan adanya suatu keadilan yang berdasarkan kepada Tuhan Yang Maha Esa telah terwujud dalam isi putusan yang dapat diterima oleh para pihak yang berperkara.

Konsep pemaknaan putusan yang menggunakan Kepala Putusan dengan irah-irah "Demi Keadilan Berdasarkan Ketuhanan Yang Maha Esa", akan berbeda jika ternyata putusan yang diberikan oleh hakim yang memeriksa perkara masih dilakukan upaya hukum oleh para pihak yang berperkara. sebagaimana disebutkan dalam undangundang bahwa memaknai upaya hukum adalah sebagai ruang yang diberikan oleh lembaga peradilan bagi terdakwa atau penuntut umum untuk tidak menerima putusan pengadilan yang bisa dari upaya perlawanan atau banding, atau kasasi atau hak terpidana untuk mengajukan permohonan peninjauan kembali asalkan sesuai dengan apayang telah diatur dalam undang-undang. ${ }^{40}$ Upaya hukum diartikan juga sebagai maksud memberikan sarana untuk melaksanakan hukum, yaitu memberi hak terdakwa/terpidana atau jaksa penuntut umum untuk tidak menerima penetapan/ putusan pengadilan karena kurang merasa adil dengan penetapan atau putusan tersebut. ${ }^{41} \mathrm{Hal}$ ini sejalan juga dengan pendapat Atang Ranoemihardja yang mengartikan bahwa upaya hukum adalah usaha yang dilakukan dengan melalui jalur hukum yang telah ditentukan alurnya oleh undang-undang untuk para pihak yang dalam menilai putusan hakim masih belum mendapatkan rasa keadilan yang diinginkan atau kurang tepat, 42 berkaitan dengan pemaknaan upaya hukum, Suryono menekankan bahwa adapun maksud upaya hukum tersebut, adalah upaya untuk kesatuan peradilan dimana memberikan ruang dalam usaha perbaikan kesalahan yang telah dilakukan oleh instansi yang sebelumnya, ${ }^{43}$ maka berdasarkan pengertian dan maksud dari upaya hukum tersebut diketahui bahwa pengertian pokok upaya hukum adalah apabila para pihak merasa putusan yang diberikan adalah tidak adil, maka dapat dipastikan pula dalam

\footnotetext{
${ }^{39}$ Munir Fuady, Dinamika Teori Hukum, Bogor: Ghalia Indonesia, 2007, h. 113.

${ }^{40}$ Diatur dalam Bab I Pasal 1 Angka 12 KUHAP.

${ }^{41}$ A. Hamzah dan Irdan Dahlan, Upaya Hukum dalam Perkara Pidana, Jakarta: PT. Bina Aksara, 1987, h. 3.

42 R. Atang Ranoemihardja, Hukum Acara Pidana, Bandung: Tarsito, 1981, h. 123.

43 Suryono Sutarto, Hukum Acara Pidana, Jilid II, Semarang: Badan Penerbit Universitas Diponegoro, 2004, h. 85.
} 
putusan tersebut belum memberikan keadilan bagi pihak yang menginginkan adanya keadilan dalam berperkara.

Putusan hakim yang berkualitas, harus mampu mencerminkan apa makna yang seharusnya didapat oleh para pencari keadilan ketika mereka mendatangi peradilan, sehingga para hakim yang melakukan pemeriksaan benar benar melakukan pemeriksaan untuk mencari dan keadilan. Hakim yang akan menjatuhkan putusan sudah seharusnya memberikan putusan yang isi di dalamnya memberikan nilai kebenaran, sehingga hal tersebut dapat diterima oleh masing-masing pihak yang berperkara. Terhadap putusan yang masih belum diterima oleh para pihak, maka putusan tersebut lebih tepat jika tidak diberikan terlebih dahulu Keppu DKBKYME, hal ini untuk menandakan bahwa proses keadilan dalam perkara tersebut masih belum memberikan gambaran keadilan sebagaimana Keadilan yang benar benar menggambarkan keadilan yang didasarkan atas Rida Tuhan Yang Maha Esa, hal ini adalah untuk menjaga hakikat dari makna irah-irah tersebut, yang menegaskan bahwa proses untuk dalam perkara pengadilan haruslah untuk mendapatkan keadilan yang seadil adilnya yang dapat dipertanggunggjawabkan tidak hanya kepada Tuhan tetapi juga terhadap masyarakat pencari keadilan.

Terhadap suatu putusan yang belum mempunyai kekuatan hukum tetap yang tidak perlu diberikan irah irah tersebut, tentunya bisa menimbulkan suatu pertanyaan bilamanakah suatu pemeriksaan perkara tersebut sudah pada tahap Kasasi dimana pemeriksaan kasasi adalah pemeriksaan terakhir dalam suatu perkara pidana dan ternyata pada putusan kasasi, masih terdapat salah satu pihak yang berperkara masih menyatakan bahwa belum mendapatkan keadilan yang seadil adilnya, apakah terhadap putusan Kasasi tersebut juga tidak perlu diberikan irah irah yang menyebutkan "Demi Keadilan Berdasarkan Ketuhanan Yang Maha Esa"? Untuk menjawab hal tersebut, tentunya perlu dipahami terlebih dahulu bahwa terdapat suatu asas dalam proses peradilan yang menyatakan bahwa setiap perkara harus ada akhirnya (Litis Finiri Oportet). Asas ini tidak terlepas dari salah satu tujuan hukum yaitu memberikan suatu kepastian hukum yang mana kepastian hukum ini harus ada untuk tetap meberikan ketertiban yang nantinya terdapat dalam masyarakat. Kepastian hukum adalah hal yang konkret yang ditentukan oleh hukum termasuk konsekuensi hukumnya sehingga memberikan kejelasan pengaturan perilaku yang bersifat umum dan mengikat bagi semua orang yang berada di wilayah negara. ${ }^{44}$ Kepastian hukum digunakan untuk menjaga makna hukum sehingga dapat terus digunakan sebagai pedoman perilaku bagi tiap individu sehingga hal ini merupakan wujud dan gambaran yang tidak dapat dipisahkan dari hukum terutama untuk norma hukum tertulis. ${ }^{45}$

Jika mengacu pada asas kepastian hukum yang berkaitan dengan asas bahwa setiap perkara tentunya harus mempunyai nilai akhir dan dapat diselesaikan (Litis Finiri Oportet), apakah kemudian dengan asas tersebut tetap tidak didapatkan suatu keadilan?

44 Van Apeldoorn, Pengantar Ilmu Hukum, Jakarta: Pradnya Paramita, 1990 h. 24-25.

45 Fence M. Wantu, "Antinomi dalam Penegakan Hukum oleh Hakim", Jurnal Berkala Mimbar Hukum,Vol. 19 No. 3 Oktober 2007, Yogyakarta: Fakultas Hukum, Universitas Gadjah Mada, h. 193. 
Putusan hakim haruslah putusan yang berkualitas yang artinya putusan tersebut mampu untuk dijadikan pedoman karena memiliki segi pertanggungjawaban dari sudut pandang dan aspek kepastian hukum (rumusan pasal dalam undang-undang) dan kemanfaatan bagi para pihak semata, namun dalam putusan hakim haruslah memberikan suatu gambaran keadilan dan nilai nilai kemanusiaan. ${ }^{46}$ dalam hal inilah tentunya letak mengapa hakim Mahkamah Agung haruslah benar-benar dipilih dari hakim yang berintegritas, yang harus menunjukkan bahwa dia adalah sebagai wakil Tuhan yang bertanggung jawab kepada agama dan kepercayaannya, hakim tersebut yang secara moral harus berani memutuskan bahwa keadilan adalah hal yang memang harus ada yang memutuskan kebenarannya, sehingga disinilah letak dari tanggung jawab lebih Hakim Agung daripada hakim biasa, karena ia yang nantinya akan mempertanggung jawabkan kepada Tuhannya sesuai dengan agama dan keyakinannya.

Penentuan irah-irah tersebut tentunya akan kembali suatu pemikiran yang lebih mendalam, karena ternyata dalam proses perkara pidana masih ada upaya hukum luar biasa, yaitu adanya Peninjauan Kembali (PK), apakah hal ini kembali menghilangkan makna dari kepala putusan yang telah disebutkan dalam putusan kasasi. Peninjauan kembali dapat dikabulkan jika terdapat adanya bukti baru (novum) yang sebelumnya tidak diketahui oleh hakim, maka dapat diartikan bahwa meskipun Keppu DKBKYME telah muncul dalam putusan kasasi, dan pada akhirnya putusan tersebut berubah dengan adanya bukti baru yang diajukan dalam PK, bukan berarti PK ini mengkaburkan makna keadilan dalam kepala putusan tersebut, karena perlulah dipahami terlebih dahulu bahwa pada saat putusan kasasi dikeluarkan, hakim berdasarkan keyakinannya telah mempertimbangkan bukti bukti yang ada pada saat itu, jika ternyata pada saat suatu perkara dilakukan PK dan PK tersebut dikabulkan oleh hakim, maka sebenarnya PK ini memberikan penegasan bahwa ada suatu keadilan yang kembali ditemukan dengan adanya bukti baru yang sebenarnya kalau bukti baru tersebut diketahui pada saat pemeriksaan kasasi tentunya hakim pemeriksa perkara tersebut tentunya akan memberikan putusan yang sama sebagaimana disebutkan dalam putusan peninjauan kembali tersebut.

Konsep pemberian Keppu DKBKYME disematkan hanya untuk sebuah putusan yang mempunyai kekuatan hukum tetap adalah sejalan dengan merujuk pada pendapat Plato yang menggambarkan keadilan adalah sebagai sesuatu diluar kemampuan manusia biasa dan hanya para ahli yang bisa mendalami hal tersebut, sehingga Plato membagi keadilan atas keadilan yang terwujud jika mampu memberikan keseimbangan antara hak dan kewajiban (keadilan moral) dan Keadilan tercipta dengan adanya seseorang yang telah melaksanakan sesuai dengan tahapan dan cara yang diinginkan (keadilan procedural), maka kepala putusan yang menyebutkan “Demi Keadilan Berdasarkan Ketuhanan Yang Maha Esa" hanya bagi putusan yang telah memperoleh kekuatan hukum tetap, diharapkan mampu mmberikan gambaran penyatuan keadilan moral dan prosedural dimana didalam keadilan prosedural juga memberikan gambaran keadilan moral, atau

${ }^{46}$ Sri Sutatiek, Menyoal Akuntabilitas Moral Hakim Pidana dalam Memeriksa, Mengadili, dan Memutus Perkara, Yogyakarta:Aswaja, 2013, h. 29. 
keadilan moral telah terimpilkasi dan terurai dengan baik pemaknaannya dalam suatu keadilan prosedural.

\section{PENUTUP}

\section{Kesimpulan}

1. Keppu DKBKYME adalah suatu pemaknaan bahwa seharusnya isi putusan tersebut berisi tentang suatu proses dalam mencapai suatu keadilan yang dapat dipertanggungjawabkan kebenarannya baik kepada Tuhan Yang Maha Esa dan juga kepada diri sendiri dan rakyat. bertanggung jawab kepada Tuhan Yang Maha Esa, diartikan bahwa dalam membuat putusan tersebut hakim memutuskan sesuai dengan kaidah agama dan kepercayaan masing-masing, dan dalam kepada diri sendiri, diartikan sebagai tanggung jawabnya sebagai penegak hukum yang bertugas untuk mengadili suatu perkara, dan kepada rakyat dimana dalam putusan tersebut harus mencerminkan keadilan yang dapat diterima oleh seluruh rakyat Indonesia pada umumnya.

2. Terhadap putusan yang masih belum diterima oleh para pihak, maka putusan perkara pidana lebih tepat jika tidak diberikan terlebih dahulu Keppu DKBKYME, hal ini untuk menandakan bahwa proses keadilan dalam perkara tersebut masih belum memberikan gambaran keadilan sebagaimana keadilan yang berdasarkan Ketuhanan Yang Maha Esa, hal ini adalah untuk menjaga hakikat dari makna irah-irah tersebut, yang menegaskan bahwa proses untuk dalam perkara pengadilan haruslah untuk mendapatkan keadilan yang seadil adilnya yang dapat dipertanggunggjawabkan tidak hanya kepada Tuhan tetapi juga terhadap masyarakat pencari keadilan.

\section{Saran}

Terhadap paradigma Keppu DKBKYME hanyalah dapat disematkan kepada putusan yang telah berkekuatan hukum tetap, dapatlah dijadikan masukan untuk perubahan terhadap pembuatan undang-undang hukum acara pidana yang baru, hal ini untuk lebih menegaskan kemanfaatan dan makna sesungguhnya dari kepala putusan yang berbunyi "Demi Keadilan Kepada Tuhan Yang Maha Esa".

\section{DAFTAR PUSTAKA}

Buku:

A. Hamzah dan Irdan Dahlan, Upaya Hukum dalam Perkara Pidana, Jakarta: PT. Bina Aksara, 1987.

Aloysius Wisnubroto, Hakim dan Peradilan di Indonesia dalam Beberapa Aspek Kajian, Yogyakarta: Universitas Atmajaya, 1997.

Andi Hamzah, Hukum Acara Pidana Indonesia, Jakarta: PT. Rineka Cipta, 2000.

Antonius Sudirman, Hati Nurani Hakim dan Putusannya : Suatu Pendekatan dari Perspektif Ilmu Hukum Perilaku (Behavioral Jurisprudensi) Kasus Hakim Bismar Siregar, Bandung: Citra Aditya Bakti, 2007.

Bagir Manan, Sistem Peradilan Berwibawa (Suatu Pencarian), Jakarta: Mahkamah Agung RI, 2007. 
Barda Nawawi Arief, Sistem Peradilan Pidana Terpadu (Intergrated Criminal Justice System). Semarang: Universitas Diponegoro, 2006.

Barda Nawawi Arief, Teori-Teori dan Kebijakan Pidana, Bandung: Alumni, 1992.

Bismar Siregar, Rasa Keadilan, Surabaya: PT.Bina Ilmu, 1996.

Dahlan Sinaga, Kemandirian dan Kebebasan Hakim Memutus Perkara Pidana Dalam Negara Hukum Pancasila, Suatu Perspektif Teori Keadilan Bermartabat, Bandung:Nusa Media, 2015.

E. Fernando M. Manullang, Menggapai Hukum Berkeadilan Tinjauan Hukum Kodrat dan Antinomi Nilai, Cetakan 1, Buku Kompas, Jakarta: PT. Kompas Media Nusantara, 2007.

Frans Hendra Winarta, Bantuan Hukum Suatu Hak Asasi Manusia Bukan Belas Kasihan, Jakarta: PT. Elexmedia Komputindo, Kelompok Gramedia, 2000.

HMA. Kuffal, Demi Keadilan Berdasarkan Ketuhanan Yang Maha Esa, Hakim : Antara Gaji, Keadilan, Kejujuran dan Ketaqwaan, Malang: UMM Press, 2012.

John Rawls, Teori Keadilan (A Theory of Justice), Diterjemahkan oleh Uzair Fauzan dan Heru Prasetyo, Yogyakarta: Pustaka Pelajar, 2006.

Jude P. Dougherty, Western Creed, Western Identity : Essays in Legal and Social Philosohy, CUA Press, 2010.

K Bertens, Pengantar Etika Bisnis, Yogyakarta, 2000.

Lilik Mulyadi, Putusan Hakim Dalam Hukum Acara Pidana, Bandung: Citra Adita Bakti, 2007.

M.Yahya Harahap, Pembahasan Permasalahan dan Penerapan KUHAP,Pemeriksaan Sidang Pengadilan, Banding, Kasasi, dan Peninjauan Kembali, Jakarta: Sinar Grafika, 2005

Munir Fuady, Dinamika Teori Hukum, Bogor: Ghalia Indonesia, 2007.

Nanda Agung Dewantara, Masalah Kebebasan Hakim dalam Menangani Suatu Perkara Pidana, Jakarta: Aksara Persada Indonesia, 1987.

O Notoamidjojo, Masalah Keadilan, Semarang: Tirta Amerta, 1971.

Peter Mahmud Marzuki, Penelitian Hukum Edisi Revisi, Jakarta: Kencana Prenada Media Group, 2016.

R. Atang Ranoemihardja, Hukum Acara Pidana, Bandung: Tarsito, 1981.

RH. Wiwoho, Keadilan Berkontrak, Jakarta: Penaku, 2017.

Sri Sutatiek, Menyoal Akuntabilitas Moral Hakim Pidana dalam Memeriksa, Mengadili, Dan Memutus Perkara, Yogyakarta:Aswaja, 2013.

Suryono Sutarto, Hukum Acara Pidana, Jilid II, Semarang: Badan Penerbit Universitas Diponegoro, 2004.

Teguh Prasetyo, Hukum dan Sistem Hukum Berdasarkan Pancasila, Yogyakarta:Media Perkasa, 2013.

Van Apeldoorn, Pengantar Ilmu Hukum, Jakarta: Pradnya Paramita, 1990.

Wirjono Prodjodikoro, Azas Azas Hukum Pidana di Indonesia, Bandung: Refika Adhitama, 2003.

Yesmil Anwar dan Adang, Sistem Peradilan Pidana; Konsep Komponen, dan Pelaksanaannya dalam Penegakan Hukum Di Indonesia, Bandung: Widya Padjajaran, 2009. 
Zulkarnain, Praktik Peradilan Pidana, Panduan Praktis Memahami Peradilan Pidana, Malang: Setara Press, 2016.

\section{Jurnal:}

Fence M. Wantu, "Antinomi Dalam Penegakan Hukum Oleh Hakim”, Jurnal Berkala Mimbar Hukum,Vol. 19 No. 3 Oktober 2007, Yogyakarta: Fakultas Hukum, Universitas Gadjah Mada.

HM. Soerya Respationo, "Putusan Hakim: Menuju Rasionalitas Hukum Refleksif dalam Penegakan Hukum", Jurnal Hukum Yustisia, No. 86 Th. XXII Mei-Agustus, 2013, Surakarta: Fakultas Hukum Universitas Sebelas Maret Surakarta.

Tata Wijayanta dan Herry Firmansyah, "Perbedaan Pendapat dalam Putusan Putusan Di Pengadilan Negeri Yogyakarta dan Pengadilan Negeri Sleman", Jurnal Berkala Mimbar Hukum,Vol. 23 No. 1 Februari 2011, Yogyakarta: Fakultas Hukum Universitas Gadjah Mada.

\section{Media Internet:}

http://kbbi.co.id/arti-kata/demi 